\author{
Ю. О. Павлова, С. П. Гудзь, С. О. Гнатуш \\ Львівський національний університет ім. І. Франка
}

\title{
ВПЛИВ ФАКТОРІВ СЕРЕДОВИЩА НА РІСТ І СИНТЕЗ ПІГМЕНТІВ ПУРПУРОВИМИ СІРКОВИМИ БАКТЕРІЯМИ
}

Досліджено вплив різних факторів середовища на ріст і синтез пігментів окремими штамами пурпурових сіркових бактерій родів Chromatium, Thiocystis, Thiocapsa і Lamprocystis, виділених із водойм Яворівського сіркового родовища. Для оптимального росту бактерій у середовище необхідно вносити кальцій, магній, манган, ферум, хлорид натрію. Внесення цих елементів дозволяє значно підвищити вихід біомаси бактерій і синтез ними каротиноїдів та бактеріохлорофілу $a$. Суттєвий вплив на ріст пурпурових сіркових бактерій виявляє початкова концентрація посівного матеріалу та донора електронів. Після окиснення сульфіду на початкових етапах розвитку культури спостерігається уповільнення росту і руйнування клітин під дією світла. Для оптимізації росту бактерій донор електронів (сульфід) необхідно вносити багаторазово у процесі культивування в концентрації, що не перевищує інгібуючу дозу. Додаткове внесення до середовища донора електронів сприяс зростанню біомаси клітин. Позитивний вплив на синтез пігментів виявляс внесення до середовища ацетату. Необхідною умовою для росту та синтезу пігментів с інтенсивність освітлення. Максимальний ріст культур спостерігали при освітленості 400 лк. Зростання інтенсивності освітлення супроводжусться зниженням темпів росту і вмісту каротиноїдів та бактеріохлорофілу а у клітинах. У всіх штамів синтез пігментів пригнічусться киснем.

\section{Y. O. Pavlova, S. P. Gudz', S. O. Gnatush \\ I. Franko Lviv National University}

\section{INFLUENCE OF ENVIRONMENTAL FACTORS ON GROWTH AND PIGMENT SYNTHESIS BY PURPLE THIOBACTERIA}

The influence of different environmental factors on growth and pigment biosynthesis by particular strains of purple thiobacteria was investigated. These strains belong to the genus Chromatium, Thiocystis, Thiocapsa and Lamprocystis and were isolated from Yavoriv sulphur mine. Calcium, magnesium, manganese, iron and sodium chloride should be included in the medium for optimal growth of these bacteria. Addition of these elements entails increasing the biomass production and synthesis of carotenoids and bacteriochlorophyll $a$. Initial concentration of inoculum and electron donor has essential influence on growth of purple thiobacteria. Early in the development of culture, sulphide was oxidized, and then the growth impairment and destruction of cells under exposure of light were observed. For the optimization of bacteria growth the electron donor (sulphide) must be added many times during the cultivation process in the concentration, which is not exceed an inhibition dose. The additional bringing of the electron donor in the medium promotes the raise of cells' biomass. The acetate introduction in the medium has positive influence on the pigments' biosynthesis. The essential factor of growth and pigments' biosynthesis is the light intensity. Peak gain of the culture growth was observed under $400 \mathrm{~lx}$. The amplification of light exposure is accompanied by the decrease of growth and content of pigments in cells. Oxygen inhibits the synthesis of pigments in all strains.

\section{Вступ}

Представники родини Chromatiaceae, що включає пурпурові сіркові бактеріï, $є$ облігатними фототрофами. У цих організмів фотосинтез відбувається з використанням

(C) Ю. О. Павлова, С. П. Гудзь, С. О. Гнатуш, 2008 
сірководню як донора електронів [14]. Фотосинтетичний апарат пурпурових сіркобактерій складається з трьох типів пігмент-протеїнових комплексів: двох видів антен світлозбирального комплексу та реакційного центру $[7 ; 13 ; 15]$. Усі компоненти фотосинтетичного апарату містять каротиноїди та бактеріохлорофіли $[7 ; 13 ; 15]$. Каротиноїди широко розповсюджені у природі, вони зумовлюють забарвлення клітин бактерій, дріжджів, грибів, рослин і тварин, а $\beta$-каротин $€$ попередником вітаміну $A$ та ретиналю [9]. Деякі з них ( $\beta$-каротин, лікопен та інші) мають імуномодулюючі властивості для людини та тварин, стимулюють фагоцитоз і вироблення цитокінів, попереджують злоякісну трансформацію клітин [8; 9]. Каротиноїди поглинають світло в області 450-570 нм [15] і захищають клітину від фотопошкоджень [9].

У бактерій, що здійснюють аноксигенний фотосинтез, описано понад 100 різних каротиноїдів, вивчено шляхи їх біосинтезу та визначено основні фактори, що впливають на ці процеси $[11 ; 13 ; 15]$. Проте більшість робіт присвячена дослідженню пігментів у пурпурових несіркових бактерій $[7 ; 9 ; 13 ; 15]$. Завдання нашої роботи - виявити вплив різних факторів на утворення пігментів пурпуровими сірковими бактеріями, які під час росту на мінеральних середовищах здійснюють фотолітоавтотрофний тип живлення.

\section{Матеріал і методи досліджень}

У дослідах використовували культури пурпурових сіркобактерій Chromatium sp. 1, Chromatium sp. 2, Thiocystis sp., Thiocapsa sp., Lamprocystis sp., виділені з водойм Яворівського сіркового родовища. Культури вирощували на рідких середовищах Ван Ніля [6], Шлегеля [6], Ларсена [6], Пфенніга [14], середовищі АТСС № 1449 у скляних пробірках об'ємом 50 мл, які закривали стерильними гумовими корками так, щоб не залишилось пухирців повітря. Час культивування - 10 діб при температурі $+28^{\circ} \mathrm{C}$ за умов постійного освітлення. Як джерела освітлення використовували лампи розжарювання різної потужності. Різну інтенсивність світла створювали зміною відстані між джерелом світла та об'єктом дослідження. Інтенсивність освітлення вимірювали люксометром Ю116.

Біомасу клітин визначали турбідометрично з використанням КФК-3 ( $\lambda 540$ нм для Chromatium sp. 1, Chromatium sp. 2; 600 нм - для Thiocystis sp.; 660 нм - для Thiocapsa sp., Lamprocystis sp.). 3 метою вивчення впливу кисню на ріст культури та синтез пігментів бактерії культивували у герметично закритих колбах в умовах прямої аерації (прилад НІМА) потоком повітря (швидкість потоку $-6,5 \mathrm{~cm}^{3} / \mathrm{xв}$.).

Для визначення кількості пігментів клітини бактерій відділяли від культуральної рідини центрифугуванням при 8000 об./хв. протягом 20 хв. Супернатант зливали, клітини двічі відмивали $0,9 \% \mathrm{NaCl}$. Відмиті клітини висушували на склі та руйнували розтиранням із кварцевим піском [5]. Пігменти екстрагували сумішшю етанолу та ацетону в об'ємному співвідношенні $1: 1$ до повного знебарвлення органічного розчинника [3]. Вміст каротиноїдів та бактеріохлорофілу а розраховували на 1 г сухої маси клітин [3].

\section{Результати та їх обговорення}

Початково культивування пурпурових сіркових бактерій здійснювали на складних поживних середовищах або на синтетичних середовищах, які готували на водопровідній воді без внесення мікроелементів [1]. За цих умов культури нагромаджували незначну біомасу. Пізніші дослідження виявили позитивний вплив хлориду натрію, кальцію, цинку, мангану, міді, кобальту, бору на ріст бактерій [1]. Тому у наступних експериментах ці солі обов'язково вводилися до складу середовища. Відомо, що деякі сполуки, навіть у незначних кількостях, впливають на ріст пурпурових сіркобактерій 
(манган) або подовжують час життєдіяльності клітин (магнію сульфат), а недостатні концентрації інших речовин (кальцій) або їх неправильне співвідношення (калій/натрій) викликає аглютинацію клітин або уповільнення росту окремих штамів представників родини Chromatiaceae [1]. Крім того, усі види пурпурових сіркобактерій потребують для росту магнію та заліза, необхідних для синтезу пігментів [1]. Тому для вивчення впливу мінерального середовища на ріст і нагромадження пігментів пурпурові сіркові бактерії Thiocystis sp. і Chromatium sp. 1 культивували на різних мінеральних середовищах. Вирощені за таких умов бактерії не тільки нагромаджували різну біомасу, а й містили різну кількість каротиноїдів та бактеріохлорофілу $a$ (рис. 1).
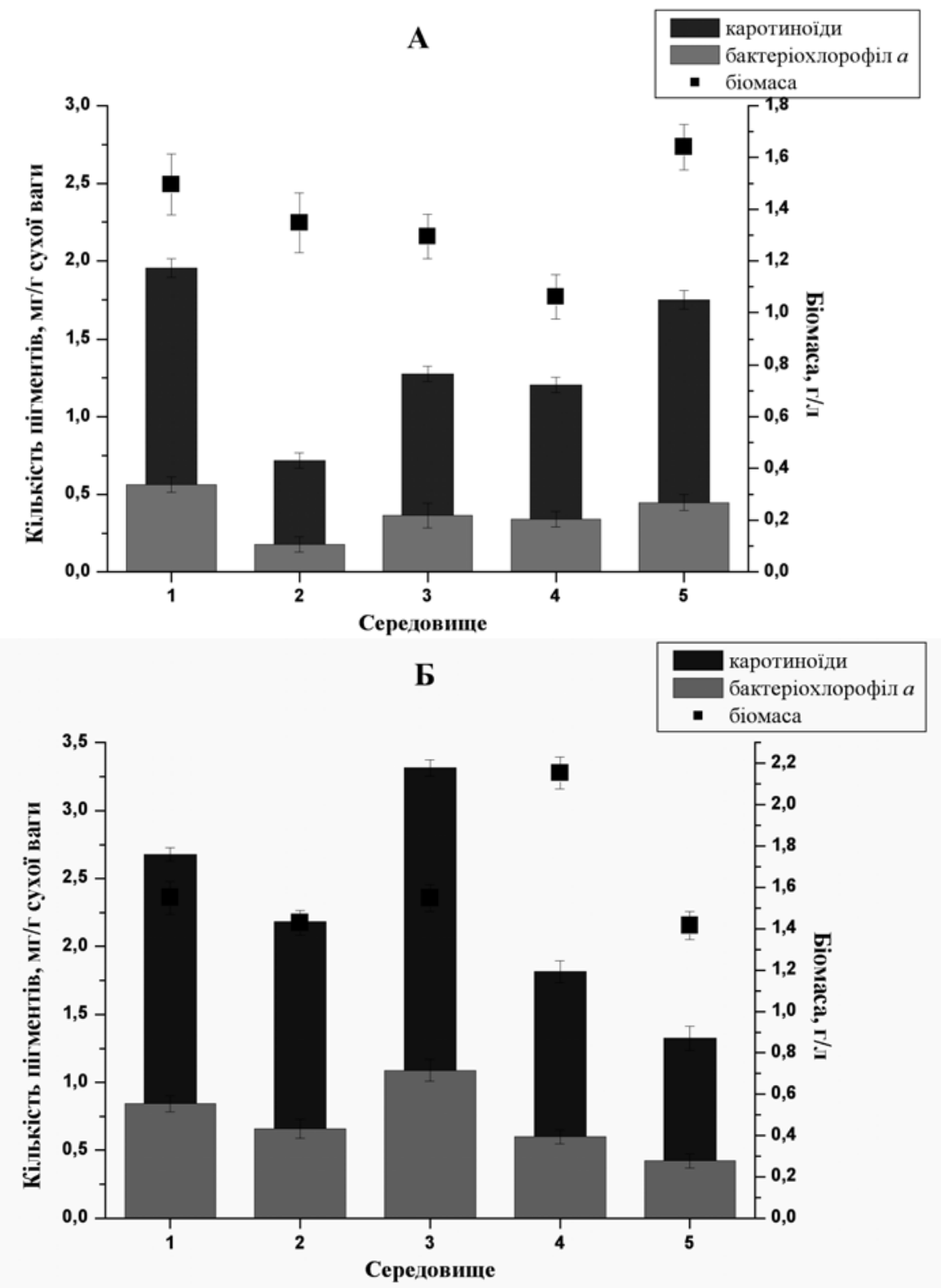

Рис. 1. Ріст і утворення пігментів Thiocystis sp. (A) та Chromatium sp. 1 (Б) на різних мінеральних середовищах: 1 - середовище Шлегеля, 2 - Ларсена, 3 - АТСС № 1449, 4 - Ван Ніля, 5 - Пфенніга. 
Культура Thiocystis sp. добре росла на середовищі Ларсена, проте утворена кількість пігментів була незначною $(0,7$ мг/г сухої ваги каротиноїдів, 0,18 мг/г сухої ваги бактеріохлорофілу $a$ ). Оптимальним для синтезу пігментів у Thiocystis sp. виявилося середовища Шлегеля та Пфенніга (рис. $1 A$ ). Мінеральний склад цих середовищ дозволяє нагромадити до 2 мг/г сухої ваги каротиноїдів. Найкращий ріст бактерій Chromatium sp. 1 забезпечувало середовище Ван Ніля, а середовище АТСС № 1449 сприяло утворенню понад 3 мг/г сухої ваги каротиноїдів 11 мг/г сухої ваги бактеріохлорофілу $a$ (рис. 15$)$.

Пурпурові сіркобактерії, вирощені фотоавтотрофно, містять менше пігментів, ніж бактерії, що виросли на середовищах із додаванням різних органічних сполук [1]. У пурпурових сіркових бактерій, подібно до зелених сіркових бактерій і вищих рослин, попередником бактеріохлорофілів $є \delta$-амінолевулінова кислота, що синтезується у цих організмах із глутамінової кислоти $[10 ; 16]$. У пурпурових несіркових, пропіоновокислих бактерій та грибів $\delta$-амінолевулінат утворюється з янтарної кислоти [16]. Із цього випливає важлива роль циклу трикарбонових кислот і його метаболітів у забезпеченні біосинтезу бактеріохлорофілів. Зважаючи на це і враховуючи результати попередніх досліджень [4], ми вивчили вплив ацетату $(0,1 \%)$ на синтез пігментів пурпуровими сірковими бактеріями (рис. 2). Виявилося, що при внесенні ацетату до поживного середовища бактерії синтезували в 1,5-2,0 раза більше пігментів.
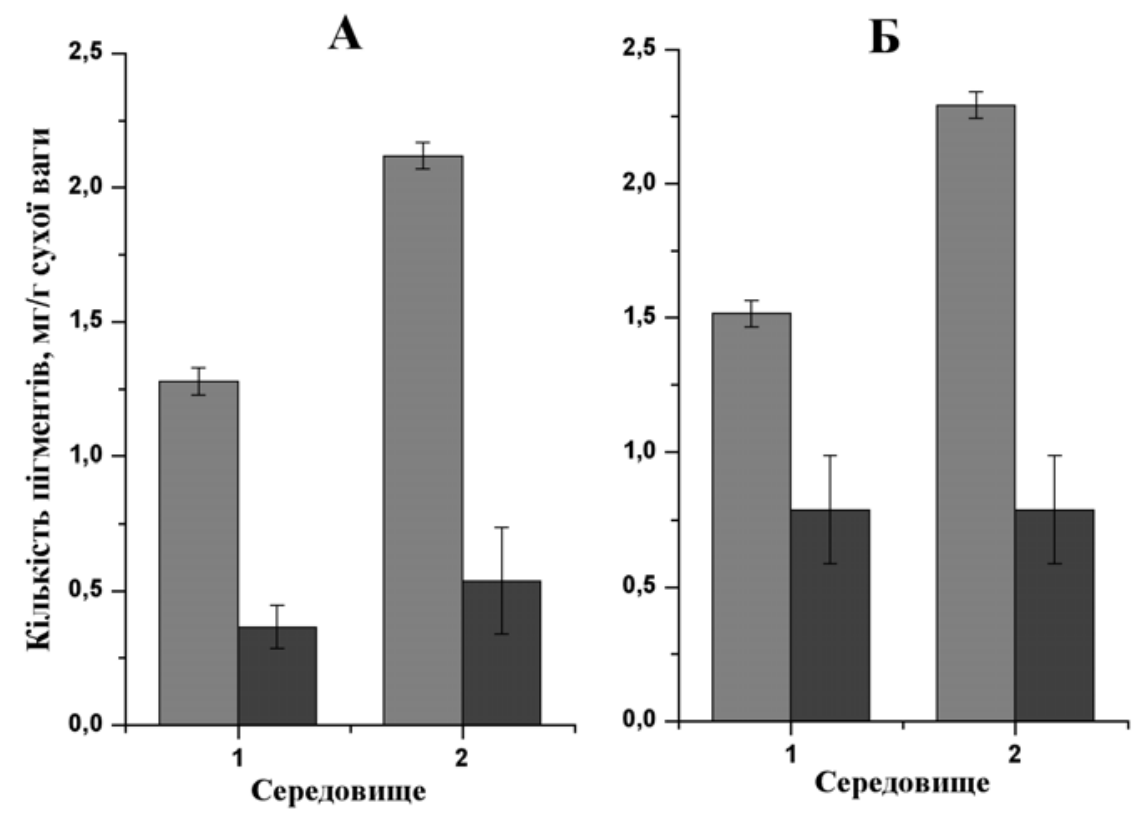

Каротиноӥди; $\square$ Бактеріохлорофіл $a$

Рис. 2. Синтез пігментів Thiocystis sp. (A) та Chromatium sp. 1 (Б)

на мінеральному середовищі (1) та на середовищі з додаванням ацетату (2).

Відомо, що після того як пурпурові сіркобактерії повністю окиснюють сульфід і внутрішньоклітинну сірку, спостерігається уповільнення росту та руйнування клітин під дією світла [14]. Подібний ефект ми спостерігали у бактерій Thiocapsa sp. і Lamprocystis sp. (рис. 3). Інтенсивність освітлення, що перевищує 300 лк, зумовлює активне відмирання клітин після 7-ї доби культивування. При освітленості менше 300 лк навіть після 168 годин може спостерігатися слабкий ріст культури (Lamprocystis sp.) (рис. 3Б). 

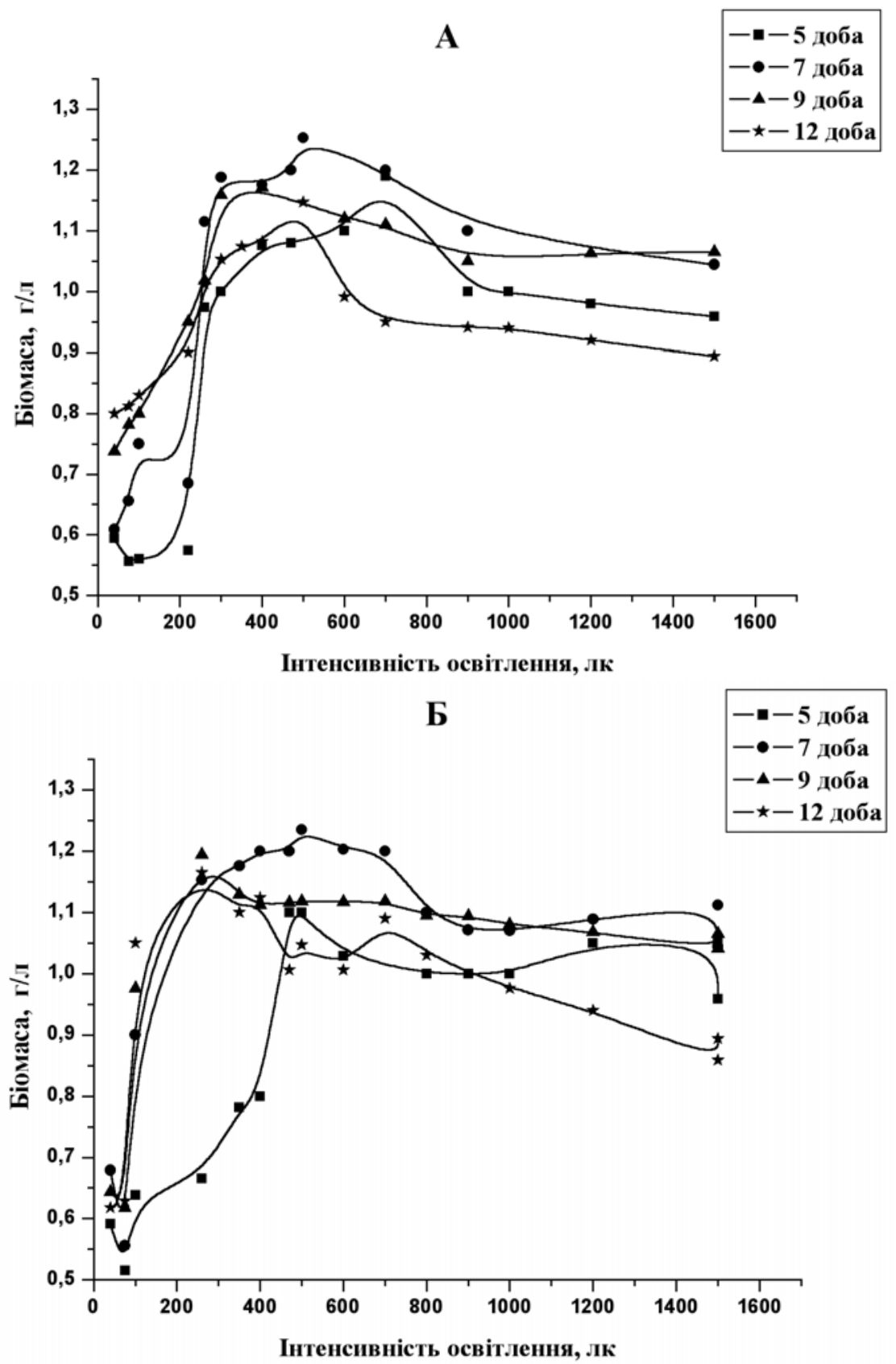

Рис. 3. Нагромадження біомаси бактеріями Thiocapsa sp. (A) і Lamprocystis sp. (Б) за умов різного освітлення після 5, 7,9 та 12 діб культивування.

Недостатня кількість сульфіду як донора електронів для фотосинтезу - головна причина незначного росту пурпурових сіркових бактерій [14]. Для підтримання росту культури та одержання високої біомаси ми додатково вносили до середовища культивування стерильний розчин сульфіду $(0,1 \%)$. Виявилось, що додаткове внесення цієї сполуки дозволяе отримати значно вищу біомасу (рис. 4). Внесення паралельно 3 сульфідом ацетату $(0,1$ \%) збільшує вихід біомаси бактерій удвічі (рис. 4). 


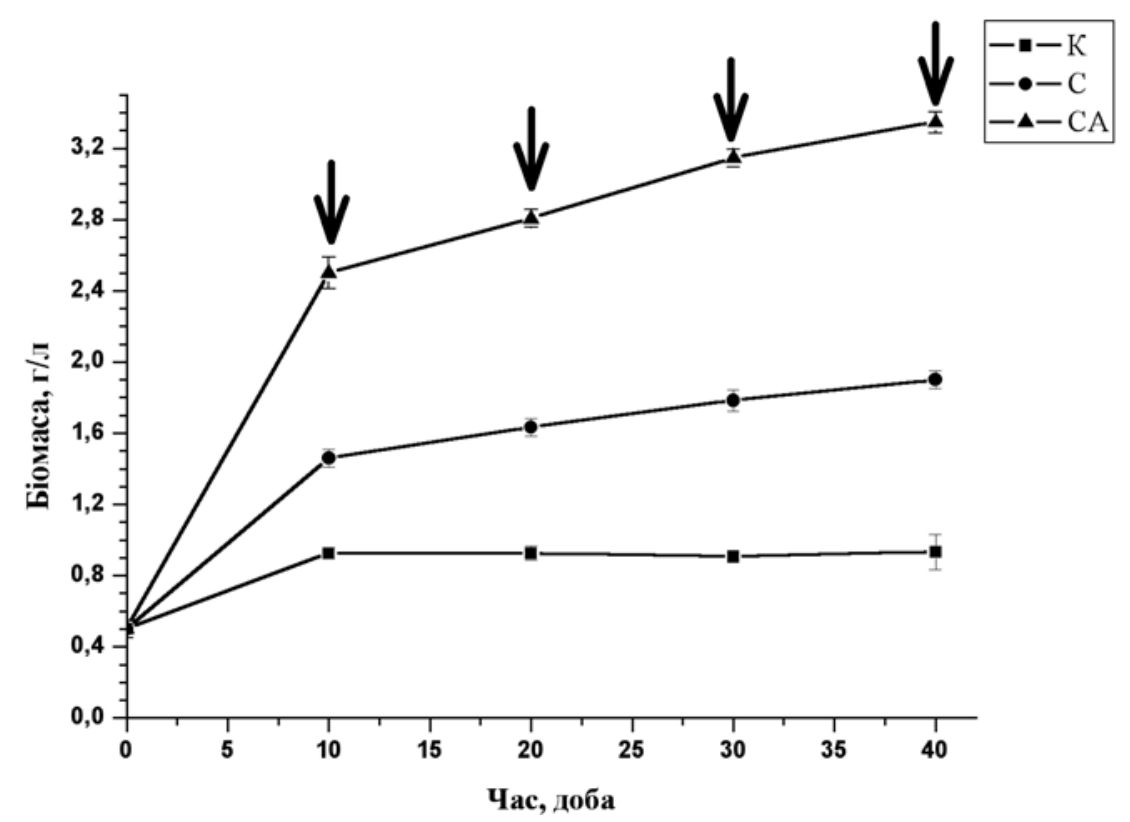

Рис. 4. Вплив додаткового внесення $(\downarrow)$ розчинів сульфіду та сульфіду і ацетату на ріст Thiocapsa sp.: $K$ - контроль, $C$ - сульфід, $C A$ - сульфід + ацетат.

Нами показано, що розвиток пурпурових сіркових бактерій в середовищі суттєво залежить від початкової кількості посівного матеріалу. Внесення 0,04-0,07 г/л уповільнює час генерації клітин і вимагає додаткового внесення донора електронів після певних проміжків часу культивування (табл. 1). Максимальну біомасу бактерії нагромаджують при внесенні інокуляту в кількості 0,4-0,6 г/л. Додаткове внесення сульфіду здійснювали через кожні 10 діб. Концентрація клітин у середовищі суттєво впливає і на нагромадження пігментів бактеріями (рис. 5). Активний синтез пігментів за умов досить високого освітлення (500 лк) корелює з великою кількістю клітин у середовищі. Це можна пояснити розвитком ефекту самозатінення клітин під час росту [2].

Табличя 1

Вплив кількості інокуляту* на ріст бактерій Thiocapsa sp.

\begin{tabular}{|c|c|c|c|}
\hline \multirow{2}{*}{$\begin{array}{c}\text { Кількість } \\
\text { інокуляту, г/л }\end{array}$} & \multicolumn{3}{|c|}{ Біомаса, г/л } \\
\hline 0,04 & на 6-у добу культивування & на 14-у добу культивування & після 1 місяця культивування \\
\hline 0,07 & 0 & 0 & $0,4 \pm 0,05$ \\
\hline 0,20 & 0 & $0,3 \pm 0,05$ & $0,5 \pm 0,05$ \\
\hline 0,40 & $0,5 \pm 0,08$ & $0,8 \pm 0,05$ & $1,0 \pm 0,10$ \\
\hline 0,60 & $1,2 \pm 0,10$ & $1,8 \pm 0,10$ & $2,0 \pm 0,04$ \\
\hline 0,70 & $2,1 \pm 0,10$ & $2,5 \pm 0,10$ & $3,0 \pm 0,05$ \\
\hline 1,50 & $1,2 \pm 0,05$ & $1,7 \pm 0,05$ & $1,8 \pm 0,10$ \\
\hline
\end{tabular}

Примітка: * - додаткове внесення сульфіду здійснювали через кожні 10 діб.

На формування внутрішніх цитоплазматичних мембран і фотосинтетичного апарату аноксигенних фототрофних бактерій впливають, в основному, два фактори: інтенсивність світла та молекулярний кисень $[12 ; 13]$. Вони діють незалежно на різні регуляторні механізми синтезу пігментів [12]. Низька освітленість сприяє розвитку фотосинтетичних мембран у клітинах бактерій та нагромадженню пігментів, а висока інтенсивність освітлення інгібує ці процеси $[12 ; 13]$. 

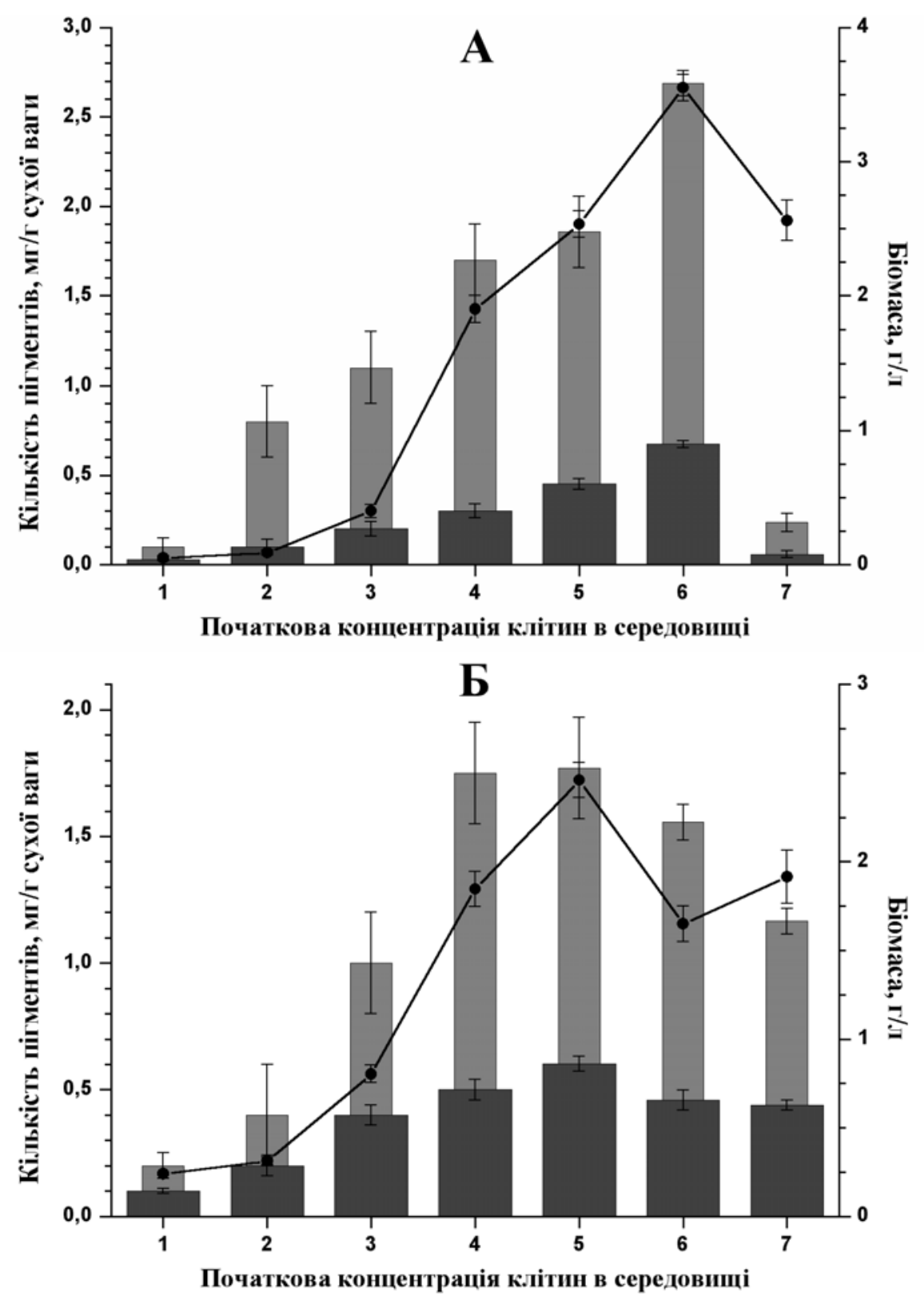

каротиноїди; $\square$ бактеріохлорофіл $a$; $\bullet-$ кі.лькість клітни після 10 діб культивування

Рис. 5. Вплив різної кількості інокуляту на ріст і синтез пігментів Thiocystis sp. (A) i Thiocapsa sp. (Б): початкова концентрація клітин у середовищі

1 - 0,04 г/л, 2 - 0,07 г/л, 3 - 0,20 г/л, 4 - 0,50 г/л, 5 - 0,60 г/л, 6 - 0,70 г/л, 7 - 1,50 г/л.

Нами показано, що у різних культурах пурпурових сіркових бактерій інтенсивність освітлення виявляє неоднакову дію на синтез пігментів (рис. 6). У Lamprocystis $s p$. за освітленості понад 80 лк спостерігаємо інгібування синтезу каротиноїдів (рис. 6A). У Chromatium sp. 1, Chromatium sp. 2 i Thiocapsa sp. максимальне нагромадження каротиноїдів спостерігали при інтенсивності освітлення 100-200 лк, а для Thiocystis $s p$. високий рівень нагромадження каротиноїдів спостерігали у широкому 170 
діапазоні освітленості (150-500 лк). Thiocystis sp. утворює найбільшу кількість каротиноїдів порівняно з іншими досліджуваними культурами. Їх рівень досягає 4,5 мг/г сухої ваги (рис. $6 A$ ). На відміну від каротиноїдів, кількість бактеріохлорофілу $а$ зменшується вже при низьких інтенсивностях освітлення (Chromatium sp. 1, Thiocapsa sp., Lamprocystis sp.) (рис. 6Б). Найвищий рівень бактеріохлорофілу $а$ спостерігали у Thiocystis sp. Кількість цього пігменту при освітленості 1000 лк була удвічі вищою порівняно з іншими досліджуваними бактеріями.
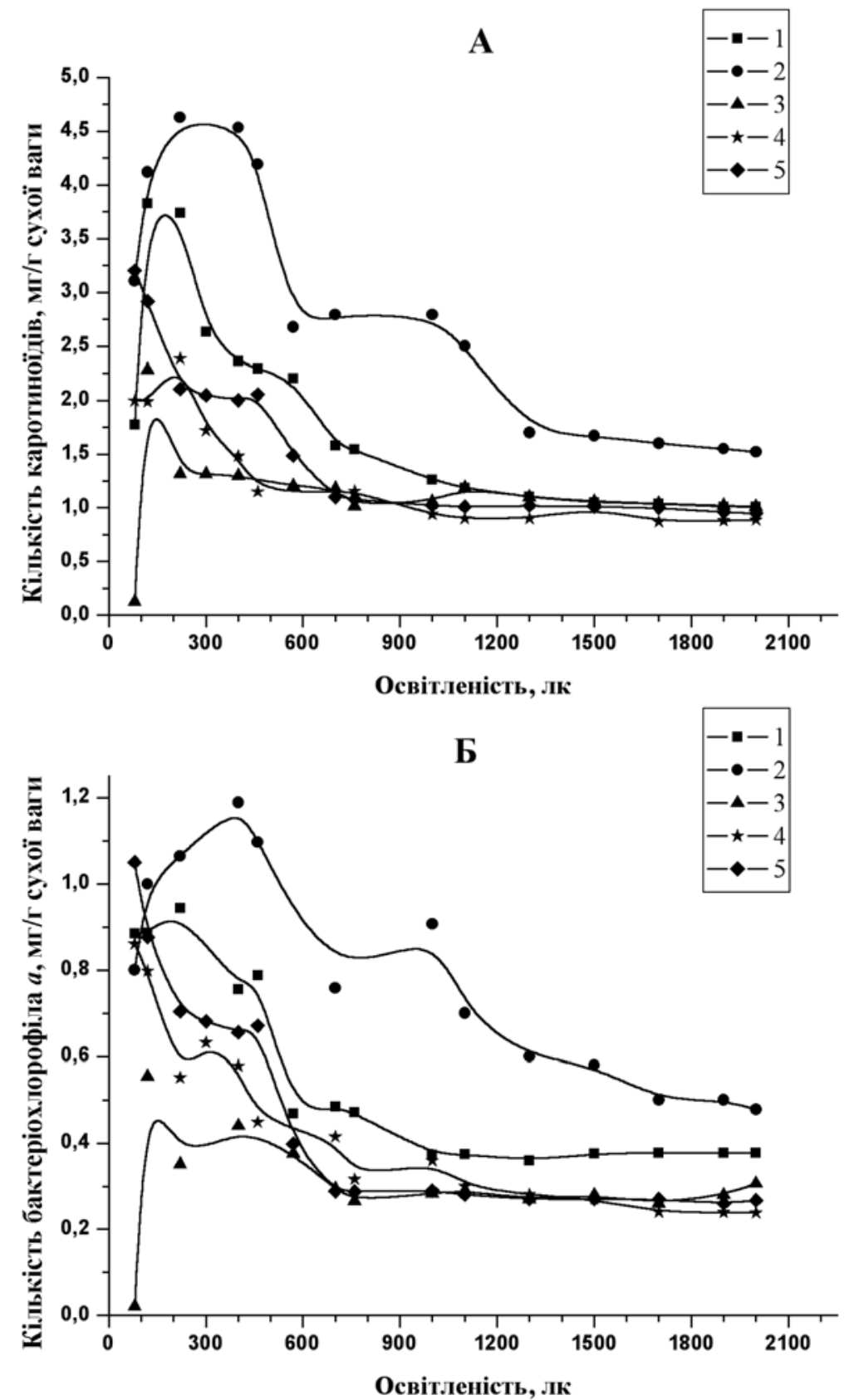

Рис. 6. Вплив інтенсивності освітлення на нагромадження каротиноїдів $(A)$ та бактеріохлорофілу а (Б) бактеріями Chromatium sp. 1 (1), Thiocystis sp. (2), Chromatium sp. 2 (3), Thiocapsa sp. (4) та Lamprocystis sp. (5). 
Молекулярний кисень виявляє сильнішу репресивну дію на формування внутрішніх цитоплазматичних фотосинтетичних мембран $[12 ; 13]$ і аерація культур фототрофних бактерій призводить до різкого зниження кількості пігментів. Однак існують види, у яких формування фотосинтетичного апарату не залежить від наявності кисню у середовищі [12]. Для виявлення впливу кисню на синтез пігментів культурами Chromatium $s p .1$ та Thiocystis sp. їх вирощували у середовищі, яке аерували шляхом постійного продування повітря. Виявилося, що за таких умов пігменти синтезуються у значно меншій кількості. Бактерії, вирощені анаеробно, синтезували приблизно у 5 разів більше каротиноїдів і у 2-3 рази бактеріохлорофілу $a$ (рис. 7).
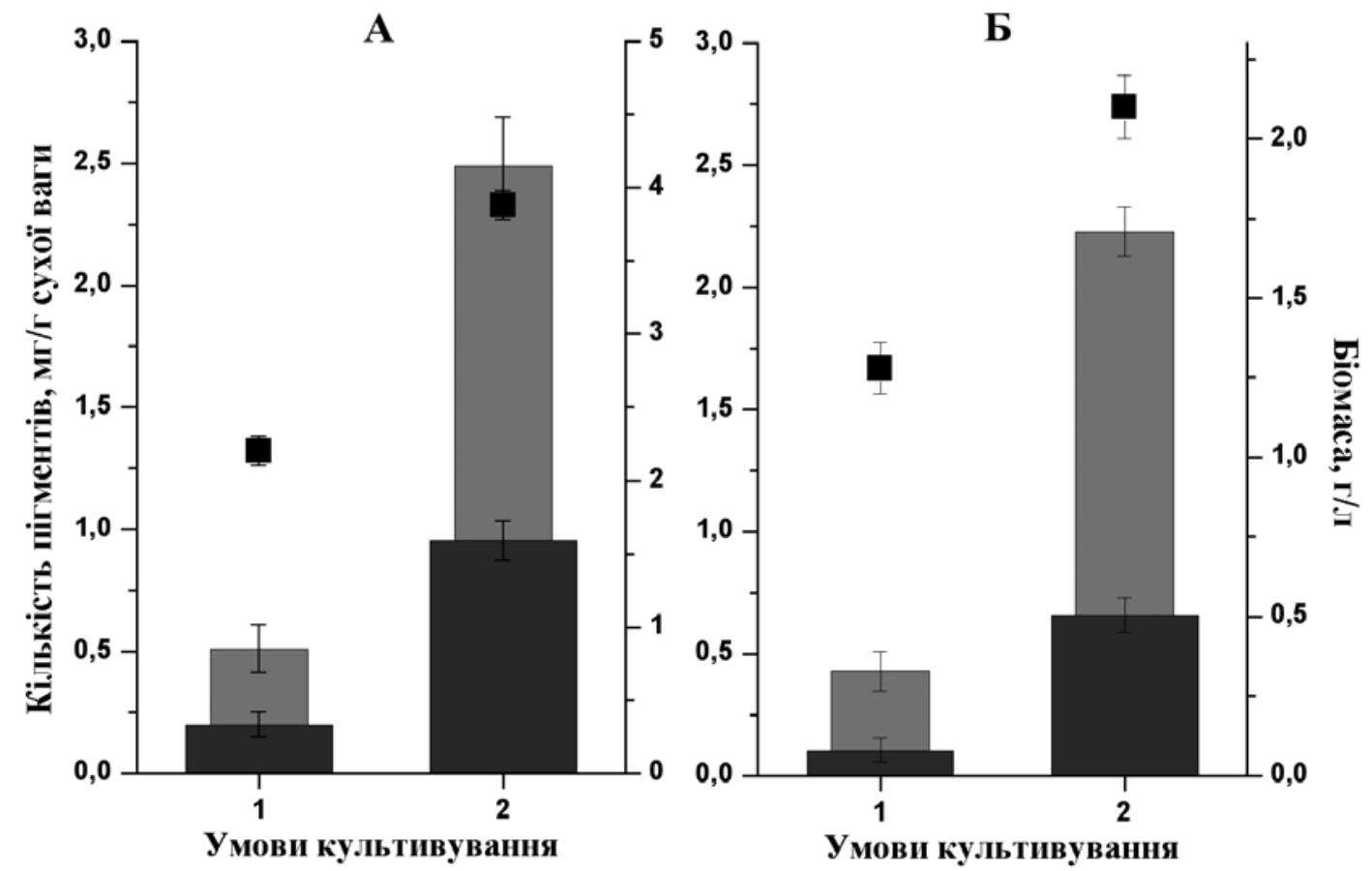

каротиноїди; — бактеріохлорофіл $a$; - біомаса

Рис. 7. Ріст і нагромадження пігментів культурами Thiocystis sp. (A) та Chromatium sp. 1 (Б) в аеробних (1) і анаеробних (2) умовах культивування.

\section{Висновки}

Пурпурові сіркові бактерії синтезують різноманітні каротиноїди, у тому числі лікопен як проміжну чи кінцеву сполуку $[11 ; 15 ; 17]$. Для максимального нагромадження пігментів цими бактеріями необхідно контролювати не тільки рівень освітленості і доступ кисню, а і склад мінерального середовища. Для швидкого нагромадження біомаси цих бактерій до середовища культивування слід вносити відповідні кількості посівного матеріалу та підтримувати певну концентрацію донора електронів. Слід відзначити, що можливість вирощувати пурпурові сіркобактерії на простих мінеральних середовищах або стічних водах має значну перевагу над пурпуровими несірковими бактеріями та дозволяє розглядати перші як модельні організми для очищення навколишнього середовища від сірководню та потенційні продуценти важливих для медицини та харчування каротиноїдів. 


\section{Бібліографічні посилання}

1. Кондратьева Е. Н. Фотосинтезирующие бактерии и бактериальный фотосинтез. - М.: Изд-во МГУ, 1972. - С. 5-45.

2. Кондратьева Е. Н. Фототрофные микроорганизмы / Е. Н. Кондратьева, И. В. Максимова, В. Д. Самуилов. - М.: Изд-во МГУ, 1989. - С. 6-82.

3. Мусієнко М. М. Спектрофотометричні методи в практиці фізіології, біохімії та екології рослин / М. М. Мусієнко, Т. В. Паршикова, П. С. Славний. - К.: Фітосоціоцентр, 2001. - 200 с.

4. Павлова Ю. О. Ріст пурпурових сіркових бактерій Thiocapsa sp. і Lamprocystis sp. в залежності від природи та інтенсивності освітлення / Ю. О. Павлова, С. П. Гудзь, А. М. Федорович // Науковий вісник Ужгород. ун-ту. Біологія. - 2007. - Т. 22. - С. 199-203.

5. Подопригора О. І. Одержання високопродуктивних штамів дріжджів Phaffia rhodozyma продуцентів каротиноїдів / О. І. Подопригора, О. В. Полулях, М. М. Дацюк // Мікробіол. журн. - 1996. - Т. 58, № 4. - С. 19-24.

6. Родина А. Г. Методы водной микробиологии: практическое руководство. - М.-Л.: Наука, 1965. $-363 \mathrm{c}$.

7. Architecture and mechanism of the light-harvesting apparatus of purple bacteria / X. Hu, A. Damjanovic, T. Ritz, K. Schulten // Proc. Nat. Acad. Sci. USA. - 1998. - Vol. 95. - P. 5935-5941.

8. Chew B. P. Role of carotenoids in the immune response // J. Dairi Sci. - 1993. - Vol. 76. P. 2804-2811.

9. Genetic and biochemical characterization of carotenoid biosynthesis mutants of Rhodobacter capsulatus / G. A. Armstrong, A. Schmidt, G. Sandmann, J. E. Hearst // The Journal of Biological Chemistry. - 1990. - Vol. 265, N 14. - P. 8329-8338.

10. Fujita Y. Chlorophylls // Encyclopedia of life sciences. - Nature publishing group, 2001.

11. Kovacs A. T. Genes involved in the biosynthesis of photosynthetic pigments in the purple sulfur photosynthetic bacterium Thiocapsa roseopersicina / A. T. Kovacs, G. Rakhely, K. L. Kovacs // Appl. Environm. Microbiol. - 2003. - Vol. 69, N 6. - P. 3093-3102.

12. Overman J. The phototrophic way of life / J. Overman, F. Garcia-Pichel // The Procaryotes: Ecophysiology and Biochemistry. - 3nd ed. - New York: Spinger, 2007. - 1107 p.

13. Pemberton J. M. Regulation of photosynthetic gene expression in purple bacteria / J. M. Pemberton, I. M. Horne, A. G. McEwan // Microbiology. - 1998. - Vol. 144. - P. 267-278.

14. Phennig N. The family Chromatiaceae / N. Phennig, H. Trüper // The Procaryotes. A Handbook on the Biology of Bacteria. Ecophysiology, Isolation, Identification, Applications. - 2nd ed. - New York: Spinger, 1992. - P. 3200-3221.

15. Pleiotropic effects of puf interposon mutagenesis on carotenoid biosynthesis in Rubrivivax gelatinosus / S. Ouchane, M. Picaurd, C. Vernotte et al. // J. Biol. Chem. - 1997. - Vol. 272, N 3. P. $1670-1676$.

16. Tangprasittipap A. 5-aminolevulinic acid from photosynthetic bacteria and its applications / A. Tangprasittipap, P. Prasertsan // Songklanakarin J. Sci. Technol. - 2002. - Vol. 24, N 4. - P. 717-725.

17. Umeno D. Diversifying carotenoid biosynthetic pathways by directed evolution / D. Umeno, A. V. Tobias, F. H. Arnold // Microbiology and molecular biology reviews. - 2005. - Vol. 69, N 1. P. 51-78.

Надійшла до редколегї 15.12.2007 